\title{
Combinatorial effects of geopropolis produced by Melipona fasciculata Smith with anticancer drugs against human laryngeal epidermoid carcinoma (HEp-2) cells
}

\author{
Ariane Rocha Bartolomeu ${ }^{a}$, Yahima Frión-Herrera ${ }^{a}$, Livia Matsumoto da Silva ${ }^{a}$, \\ Graziela Gorete Romagnoli ${ }^{\mathrm{a}}$, Deilson Elgui de Oliveira ${ }^{\mathrm{b}}$, José Maurício Sforcin ${ }^{\mathrm{a}, *}$ \\ a Department of Microbiology and Immunology, Biosciences Institute, UNESP, 18618-970 Botucatu, SP, Brazil \\ ${ }^{\mathrm{b}}$ Department of Pathology, Medical School, UNESP, 18618-970 Botucatu, SP, Brazil
}

\section{A R T I C L E I N F O}

Article history:

Received 15 February 2016

Received in revised form 30 March 2016

Accepted 31 March 2016

\section{Keywords:}

Geopropolis

Chemotherapeutic agents

Apoptosis

P-glycoprotein

\begin{abstract}
A B S T R A C T
The identification of natural products exerting a combined effect with therapeutic agents could be an alternative for cancer treatment, reducing the concentration of the drugs and side effects. Geopropolis (Geo) is produced by some stingless bees from a mixture of vegetable resins, gland secretions of the bees and soil. It has been used popularly as an antiseptic agent and to treat respiratory diseases and dermatosis. To determine whether Geo enhances the anticancer effect of carboplatin, methotrexate and doxorubicin (DOX), human laryngeal epidermoid carcinoma (HEp-2) cells were treated with Geo alone or in combination with each drug. Cell growth, cytotoxicity and apoptosis were evaluated using 3-(4,5dimethyl thiazol-2yl)-2,5-diphenyltetrazolium bromide (MTT) assay, lactate dehydrogenase (LDH) release, and flow cytometry. Scratch assay was used to analyze cell migration and transmission electron microscopy to observe morphologic alterations. The influence of Geo on drug resistance was also investigated assessing P-glycoprotein (P-gp) action. Geo inhibited cell proliferation and migration. The combination Geo + DOX led to the highest cytotoxic activity and induced apoptosis, leading to loss of membrane integrity. Geo had no effect on P-gp-mediated efflux of DOX. Data indicate that Geo combined with DOX could be a potential clinical chemotherapeutic approach for laryngeal cancer treatment.
\end{abstract}

(c) 2016 Elsevier Masson SAS. All rights reserved.

\section{Introduction}

The identification of natural products exerting a combined effect with therapeutic agents could be an alternative for cancer treatment, reducing the concentration of the drugs and side effects [1-3]. Geopropolis (Geo) is produced by some indigenous stingless bees in tropical and subtropical zones from a mixture of vegetable resins, gland secretions of the bees and soil. Geo has been used popularly because of its medicinal use as an antiseptic agent, to treat respiratory diseases and dermatosis, and to strength our natural defenses. Geo displayed an antimicrobial activity against oral pathogens and inhibited Streptococcus mutans biofilms in vitro, and exerted anti-inflammatory effects in mice [4,5]. The chemical composition of Geo produced by Melipona fasciculata Smith was previously investigated by gas chromatography coupled with mass

\footnotetext{
* Corresponding author.

E-mail address: sforcin@ibb.unesp.br (J.M. Sforcin).
}

spectrometry, revealing that its major compounds were carbohydrates and their derivatives, triterpenes, anacardic acid, alkylresorcinols and sugar alcohols [6].

Different chemotherapeutic agents such as carboplatin (CARB), methotrexate (MXT) and doxorubicin (DOX) have been widely used against neoplastic cells [7-9]. However, these therapeutic strategies may be unsatisfactory due to side effects and drug resistance [10-12]. Multidrug resistance (MDR) may be defined as resistance to various types and/or molecular structure of chemotherapeutic agents comprising different mechanisms of action, and it is a serious problem in cancer chemotherapy [13]. Among the mechanisms of MDR, the overexpression of efflux transporters in tumor cells, especially P-glycoprotein (P-gp), has attracted attention. P-gp acts as an efflux pump to expel chemotherapeutic agents from the cells, decreasing the intracellular concentration of the agents and cell resistance to them.

Laryngeal cancer is the most common malignant neoplasm among head and neck tumors. Moreover, it represents approximately $1 \%$ of all new cancer diagnoses lately and 
chemotherapy has been used for its treatment [14,15]. Immortalized cell lines have been a valuable tool for investigating detailed molecular, biochemical, genetic, and immunological properties of head and neck cancer, such as HEp-2, HEp-3, KB, FaDu, HN-1, UM-SCC-22B, UM-SCC-30, CAL27, MDA-1483, MDA-886LN, MDA-686LN, T1/CUHK, T2/CUHK, among others, as reviewed by Lin et al. [16]. HEp-2 cells contain marker chromosomes of HeLa cells. This line was originally thought to be derived from an epidermoid carcinoma of the larynx, but HeLa marker chromosomes and DNA fingerprinting were subsequently found.

Previous works from our group revealed the sensitivity of canine osteosarcoma and HEp-2 cells to Geo [6,17]. In continuity of such investigation, the effects of Geo in combination with chemotherapeutic agents were analyzed, using lower concentrations of drugs and aiming at fewer side effects to patients. The goal of this study was to determine whether Geo alone or combined with CARB, MXT and DOX could inhibit the growth of HEp-2 cells, induce apoptosis and morphological alterations, and affect the action of P-glycoprotein (P-gp), opening perspectives for new therapies including this bee product.

\section{Materials and methods}

This work was approved by the Ethics Committee, UNESP, Campus of Botucatu (CEP 1.356.549-2015).

\subsection{Chemicals and reagents}

3-(4,5-Dimethylthiazol-2-yl)-2,5-diphenyltetrazolium bromide (MTT), doxorubicin Rubidox ${ }^{\circledR}$ (Bergamo, Brazil), lyophilized methotrexate (Cruz Vermelha, Botucatu, SP Brazil), carboplatin Darrow-Vancel ${ }^{\circledR}$ Laboratories A/S (London, UK), dimethyl sufoxide (DMSO-VETEC Sigma Aldrich, USA), trypsin (TrypLE ${ }^{\mathrm{TM}}$ Express Gibco,USA), annexin V-FITC/PI apoptosis kit (Becton Dickinson, USA), lactate dehydrogenase (LDH) test kit (Sigma Aldrich, USA), resin (Araldite ${ }^{\circledR}$, Brazil) and verapamil hydrochloride (VRP-Sigma Aldrich, USA) were used.

\subsection{Cell cultures}

HEp-2 cells and African green monkey kidney (Vero) cells were obtained from the Virology Laboratory of Biotechnology Institute (IBTec, UNESP) and were mycoplasma free. Such cells were used to investigate the selectivity of Geo alone or associated to drugs against tumor or non-tumoral cells.

HEp-2 cells were grown in Minimal Essential Medium (MEMCultilab, Brazil) containing penicillin/streptomycin (1\%) and 10\% fetal bovine serum (FBS). Vero cells were maintained in Dulbecco's modified Eagle's Medium (DMEM-Cultilab, Brazil) supplemented with $10 \%$ FBS and penicillin/streptomycin (1\%). Cells were cultured in a humidified atmosphere at $37^{\circ} \mathrm{C}$ and $5 \% \mathrm{CO}_{2}$.

Sub-confluent cells were detached using trypsin-EDTA, plated at $2 \times 10^{5}$ cells $/ \mathrm{ml}$ in a 96 -well plate and incubated for $24 \mathrm{~h}$ at $37^{\circ} \mathrm{C}$ for adherence.

\subsection{Geopropolis sample}

Geo was produced in Palmeirândia, Maranhão State, northeast Brazil, by Melipona fasciculata Smith and samples were frozen at $-20^{\circ} \mathrm{C}$ before extraction. Geopropolis $(40 \mathrm{~g})$ was ground and macerated in $70 \%$ ethanol at room temperature under moderate shaking. After $24 \mathrm{~h}$, the extract was filtered and the dry weight of geopropolis hydroalcoholic extract was calculated $(9.6 \mathrm{mg} / \mathrm{ml})$. Cells were treated with different Geo concentrations (25, 50 and $100 \mu \mathrm{g} / \mathrm{ml}$ ) [6].

\subsection{Chemotherapeutic agents combined with Geo}

HEp-2 cells were incubated with DOX (0.5 and $1 \mu \mathrm{M})$, MXT (50 and $100 \mu \mathrm{M}$ ) and CARB (100 and $200 \mu \mathrm{M})$ with or without Geo $(25 \mu \mathrm{g} / \mathrm{ml})$ for 24,48 and $72 \mathrm{~h}$. Drugs concentrations were established according to literature and on previous assays standardized in our laboratory, in order to obtain the optimal concentrations to study the combination with Geo [18-20]. Before the assays, Geo and the drugs were filtered using a PES membrane (pore size $0.22 \mu \mathrm{m}-\mathrm{TPP}$, Switzerland). Control cells were incubated with medium alone. All experiments were performed in triplicate with 3 repetitions of the assays.

\subsection{Viability assay}

MTT assay was performed to assess cell viability [21]. HEp-2 and Vero cells were exposed to various concentrations of the variables for 24,48 and $72 \mathrm{~h}$. The effects of ethanol $70 \%$ (Geo vehicle) were assayed over time as well. After, $100 \mu$ l of MTT solution $(1 \mathrm{mg} / \mathrm{ml})$ were added to each well and cells were incubated for $3 \mathrm{~h}$. The formazan product were dissolved in DMSO (100 $\mu \mathrm{l})$ and absorbances were measured using an automated plate reader (BioTek Instruments, USA) at $540 \mathrm{~nm}$. Absorbance from untreated cells was considered as $100 \%$ cell viability, and percentage (\%) of cell viability was calculated according to the formula: $\%=$ [mean experimental absorbance/mean control absorbance] $\times 100 \%$.

In terms of comparison, the $50 \%$ growth inhibitory concentration $\left(\mathrm{IC}_{50}\right)$ of Geo extract was determined by interpolation of the graph of Geo concentration vs cell viability.

\subsection{Cytotoxicity assay}

To analyze the cytotoxic effects of Geo, cell membrane damage was assessed by measuring the release of lactate dehydrogenase (LDH) into the incubation medium using the LDH test kit (Sigma Aldrich, USA) and MRX revelation Dynex technologies analyzer (Germany).

\subsection{In vitro scratch assay}

The wound-healing assay was used to assess the in vitro migration ability of HEp-2 cells, culturing the cells in 24-well plates until formation of a single-layer confluence [22]. After starving overnight in serum-free medium, 200- $\mu$ l pipette tips were used to make scorings in the cell layer; followed by incubation for 24 and $48 \mathrm{~h}$ with Geo $(50$ and $100 \mu \mathrm{g} / \mathrm{ml})$. The concentration $25 \mu \mathrm{g} / \mathrm{ml}$ was not used because it exerted only a mild effect on cell viability.

Cell migration was observed in an optical microscope and measures were achieved using the software Image J (image processing and analysis in JAVA; http://rsbweb.nih.gov/ij).

\subsection{Apoptosis analysis by flow cytometry}

The induction of apoptosis by the variables was assessed by annexin V-FITC/PI apoptosis kit (Becton Dickinson, USA). Cells were seeded $\left(1.5 \times 10^{5}\right.$ cells $\left./ \mathrm{ml}\right)$ in 24 -well plates overnight and treated with the combination that led to the highest cytotoxic activity: DOX $(1 \mu \mathrm{M})$ and Geo $(25 \mu \mathrm{g} / \mathrm{ml})$ for $72 \mathrm{~h}$. Untreated cells were used as a control. Cells were centrifuged $(200 \mathrm{~g} / 10 \mathrm{~min})$ and washed twice with PBS. Staining was performed according to the manufacturer's instructions and samples were acquired in a FACSCanto $^{\mathrm{TM}}$ II (BD Biosciences, USA) Flow Cytometer with emission filters of $515-545 \mathrm{~nm}$ for FITC (green) and $600 \mathrm{~nm}$ for PI (red) using FACSDiva (BD Biosciences) software and analyzed using FlowJo software vX 10.6 (Tree Stars Inc.). The percentages of 


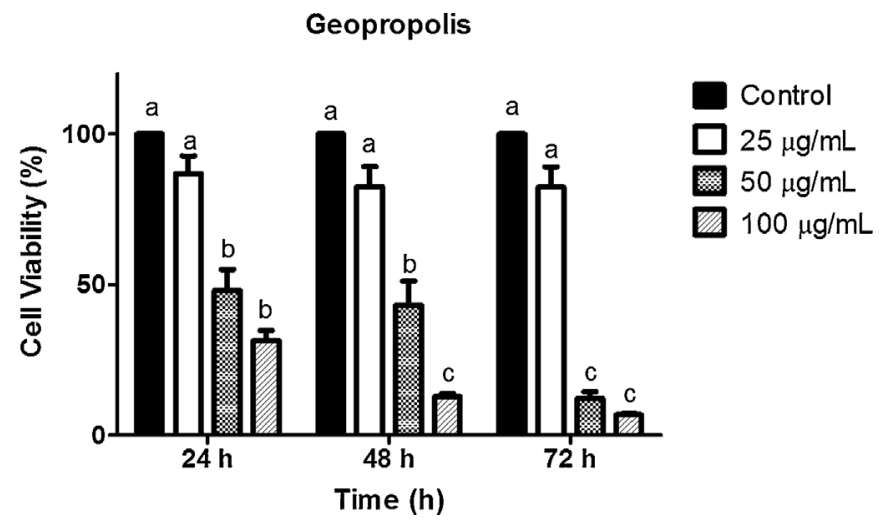

Fig. 1. Viability (\%) of HEp-2 cells after incubation with geopropolis (25, 50 and $100 \mu \mathrm{g} / \mathrm{ml}$ ) for 24,48 and $72 \mathrm{~h}$ determined by MTT assay. Data represent means \pm standard-deviation of three experiments. Different letters indicate significant differences between the treatments $(p<0.05)$.

early apoptotic $(\mathrm{AV}+, \mathrm{PI}-)$, late apoptosis or necrotic $(\mathrm{AV}+, \mathrm{PI}+)$ and live cells $(\mathrm{AV}-, \mathrm{PI}-)$ were determined.

\subsection{Morphological analysis}

The morphological characteristics of cells treated with DOX $(1 \mu \mathrm{M})$, Geo $(25 \mu \mathrm{g} / \mathrm{ml})$ or their combination for $72 \mathrm{~h}$ was determined by transmission electron microscopy (FEI Tecnai ${ }^{\mathrm{TM}}$, USA). Cells were trypsinized and centrifuged at $200 \mathrm{~g}$ for $10 \mathrm{~min}$. Afterwards, $2 \mathrm{ml}$ of cell suspension containing $2 \times 10^{5}$ cells/well were fixed in $2.5 \%$ glutaraldehyde and $4 \%$ paraformaldehyde buffered with $0.1 \mathrm{M} \mathrm{NaH}_{2} \mathrm{PO}_{4}+\mathrm{NaHPO}_{4}(\mathrm{pH} 7.3)$ and post-fixed in $0.5 \%$ osmium tetroxide $\left(\mathrm{OsO}_{4}\right)$. After dehydration in ethanol, cells were embedded in resin. Ultrathin sections were stained with uranyl acetate and lead citrate. Characteristic signs of apoptosis or necrosis (apoptotic bodies, condensation of chromatin and loss membrane integrity) were investigated.

\subsection{Effect of a P-glycoprotein inhibitor (verapamil) on HEp-2 cells}

The sensitivity of HEp-2 cells to DOX and the effects of a P-gp inhibitor (verapamil hydrochloride-VRP) were determined using the MTT assay (described above). The concentration of VRP $(5 \mu \mathrm{M})$

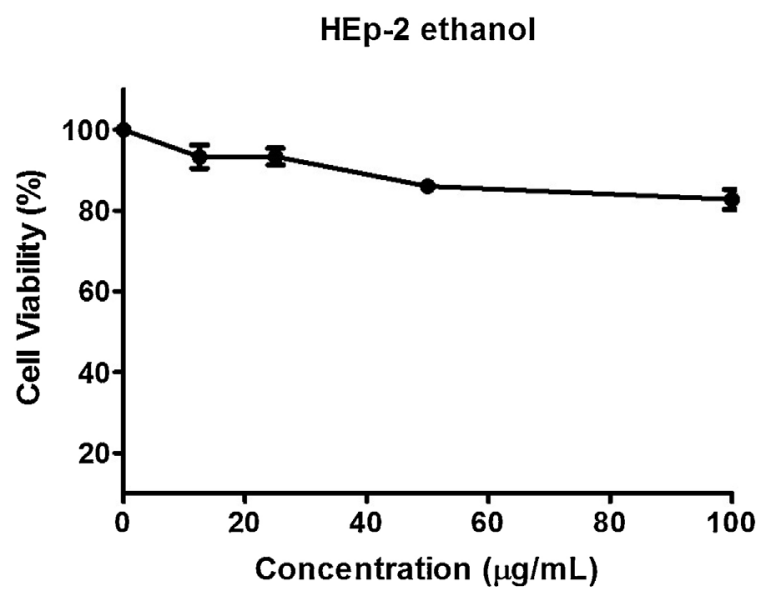

Fig. 2. Viability (\%) of HEp-2 cells after $72 \mathrm{~h}$ incubation with $70 \%$ ethanol (geopropolis solvent) by MTT assay. Ethanol concentrations were equivalent to those found in 25,50 and $100 \mu \mathrm{g} / \mathrm{ml}$ of Geo $(0.15,0.29$ and $0.59 \%)$. Data represent means \pm standard-deviation of three experiments $(p>0.05)$.
Geopropolis

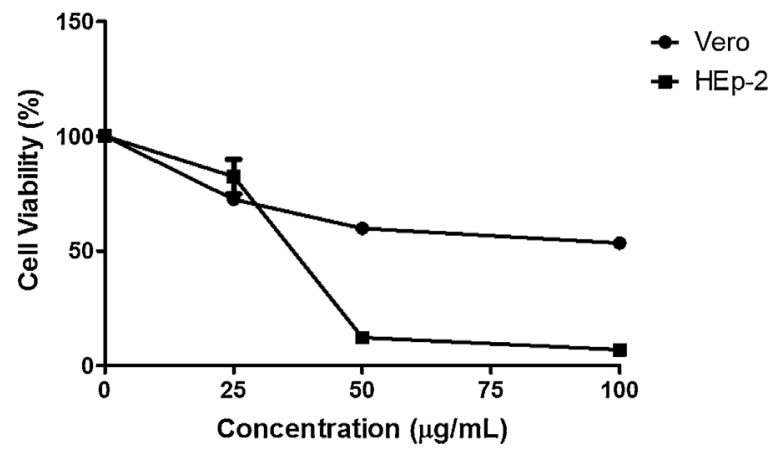

Fig. 3. Viability (\%) of HEp-2 and Vero cells after $72 \mathrm{~h}$ incubation with geopropolis $(25,50$ and $100 \mu \mathrm{g} / \mathrm{ml})$ by MTT assay. Data represent means \pm standard-deviation of three experiments.

was based on literature [19] and exerted no cytotoxic effects (data not shown).

VRP was dissolved in ethanol $70 \%$ prior to the incubation with the cells. Cells were treated with DOX $(1 \mu \mathrm{M})$, Geo $(25 \mu \mathrm{g} / \mathrm{ml})$ or their combination in the presence of VRP.HCL for $72 \mathrm{~h}$. Untreated HEp-2 cells were used as control. Assays were carried out in triplicate.

\subsection{Statistical analysis}

Data were plotted in GraphPad Prism 4.01 using the means and standard-deviation. One-way ANOVA was used for multiple comparisons followed by Tukey test. Significant differences were considered at $p<0.05$.

\section{Results}

\subsection{Effects of geopropolis extract on the growth of HEp-2 and Vero cells}

Fig. 1 shows the effects of Geo on the growth of HEp-2 cells after 24,48 and $72 \mathrm{~h}$ incubation with concentrations ranging from 25 to $100 \mu \mathrm{g} / \mathrm{ml}$. The highest inhibitory effect was seen after $72 \mathrm{~h}$. Ethanol 70\% (Geo solvent) showed no inhibitory effect on HEp2 cells (Fig. 2), and the effects of Geo on the growth of Vero cells are seen in Fig. 3.

Geo inhibited the growth of HEp-2 cells in a dose- and timedependent manner, with $\mathrm{IC}_{50}$ values of $66.86 \pm 16.08$ at $24 \mathrm{~h}$,

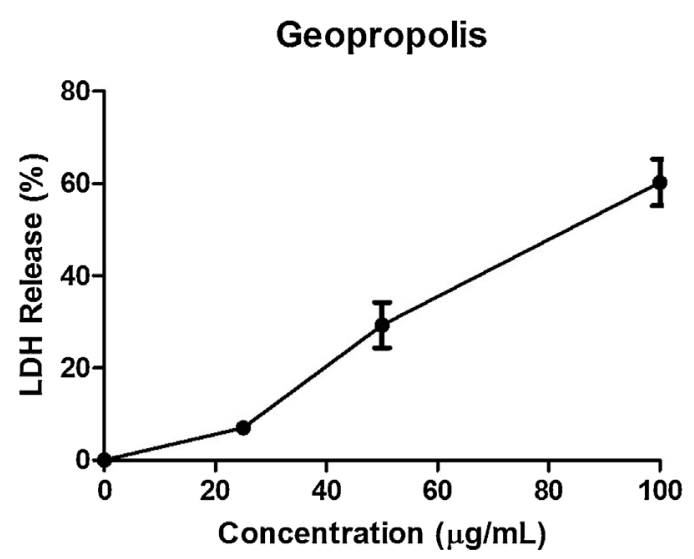

Fig. 4. LDH release (\%) by HEp-2 cells after incubation with geopropolis (25, 50 and $100 \mu \mathrm{g} / \mathrm{ml}$ ) for $72 \mathrm{~h}$. Data represent means \pm standard-deviation of three experiments. 
$54.42 \pm 19.63$ at $48 \mathrm{~h}$, and $44.10 \pm 23.88$ at $72 \mathrm{~h}$. The $\mathrm{IC}_{50}$ obtained from three independent experiments for Vero cells after $72 \mathrm{~h}$ was $91.01 \pm 10.33$, showing that Geo exhibited a selective action for tumors cells over non-tumoral ones.

\section{2. $L D H$ release assay}

Fig. 4 shows LDH release from HEp-2 cells after incubation with various concentrations of Geo for $72 \mathrm{~h}$. Geo affected cell viability using $50 \mu \mathrm{g} / \mathrm{ml}(29.3 \%)$ and $100 \mu \mathrm{g} / \mathrm{ml}$ (60.2\%). The concentration $25 \mu \mathrm{g} / \mathrm{ml}$ exhibited a mild effect on HEp-2 cells viability (7.0\%) and was used in the next assays due to its lower cytotoxic effects, to determine if Geo would exert a better action in combination with the drugs.

\subsection{In vitro migration assay}

The wound healing assay showed that Geo (50 and $100 \mu \mathrm{g} / \mathrm{ml}$ ) reduced significantly cell migration after $24 \mathrm{~h}$, while Geo $(100 \mu \mathrm{g} /$ $\mathrm{ml}$ ) was efficient only after $48 \mathrm{~h}$ (Fig. 5). Geo $(25 \mu \mathrm{g} / \mathrm{ml})$ did not affect cell migration (data not shown).
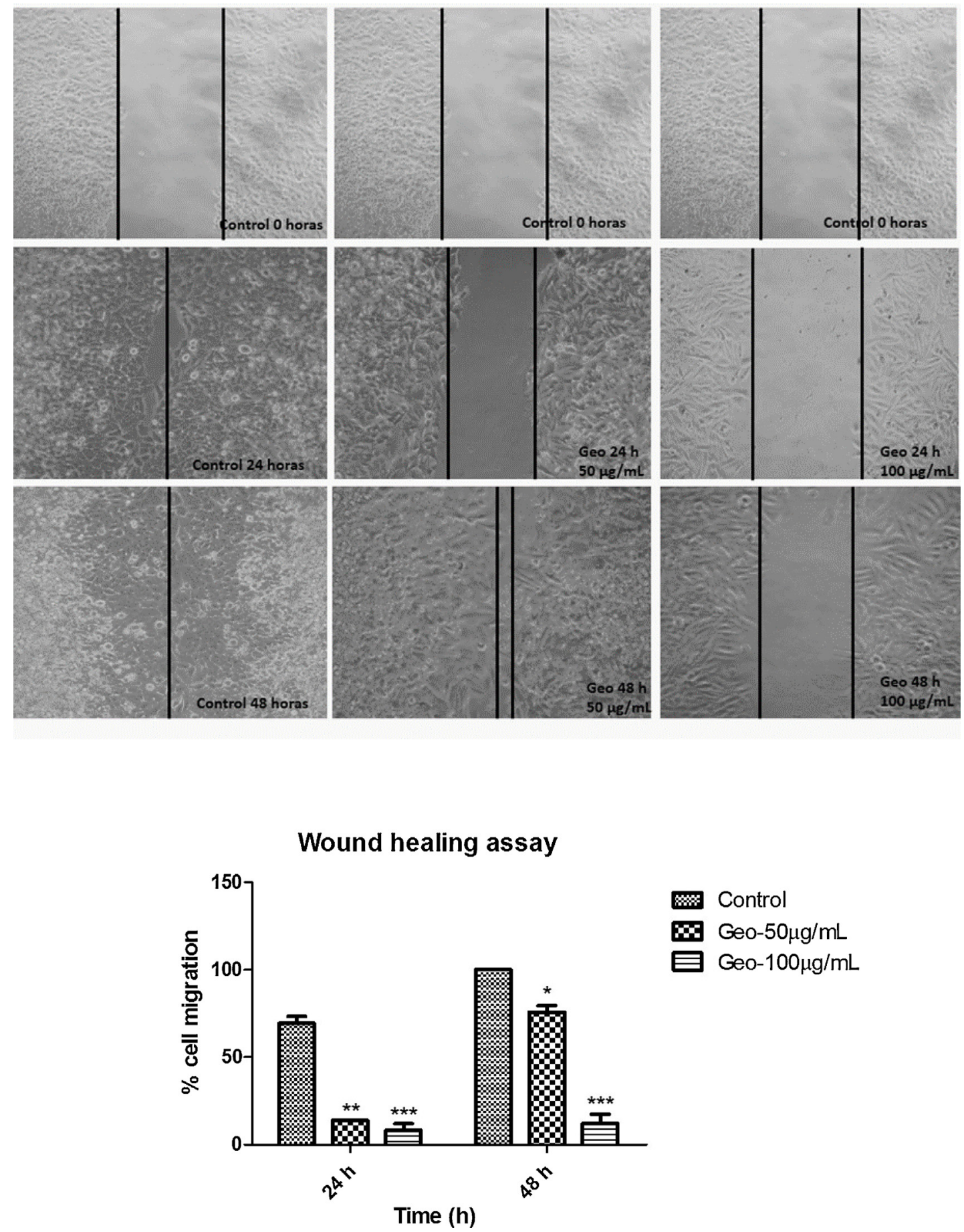

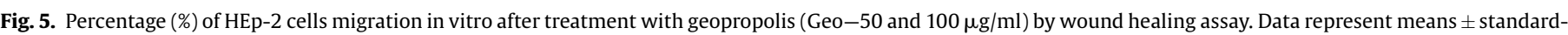
deviation of three experiments $\left({ }^{*} p<0.01 ;{ }^{* *} p<0.001 ;{ }^{* * *} p<0.0001\right.$ vs control). 


\subsection{Effects of Geo combined with DOX, MXT and CARB on HEp-2 cells viability}

The sensitivity of HEp- 2 cells to DOX (0.5 and $1 \mu \mathrm{M})$, MXT (50 and $100 \mu \mathrm{M}$ ) and CARB (100 and $200 \mu \mathrm{M}$ ) with or without Geo $(25 \mu \mathrm{g} / \mathrm{ml})$ was examined after 24,48 and $72 \mathrm{~h}$ by MTT assay.

Geo combined with MXT affected HEp-2 viability only after $24 \mathrm{~h}$ compared to monotherapy (Fig. 6a). The co-treatment with Geo + CARB showed no inhibitory effect on HEp-2 cells (Fig. 6b). The combination DOX + Geo affected significantly the sensitivity of HEp-2 cells after $72 \mathrm{~h}$ compared to DOX and Geo alone, decreasing cell viability to $43.5 \%$ (Fig. $6 \mathrm{c}$ ). Thus, the combination DOX (1 $\mu \mathrm{M})$ and Geo $(25 \mu \mathrm{g} / \mathrm{ml})$ was chosen to evaluate apoptosis, morphological changes in HEp-2 cells and the action on P-gp.

(a)

\section{Associations}

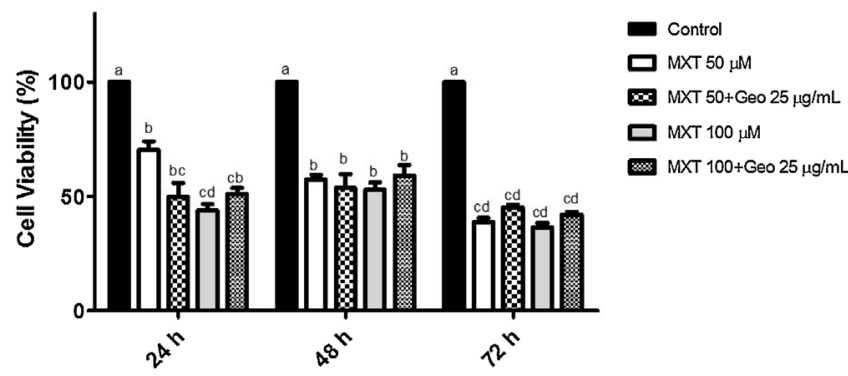

(b)

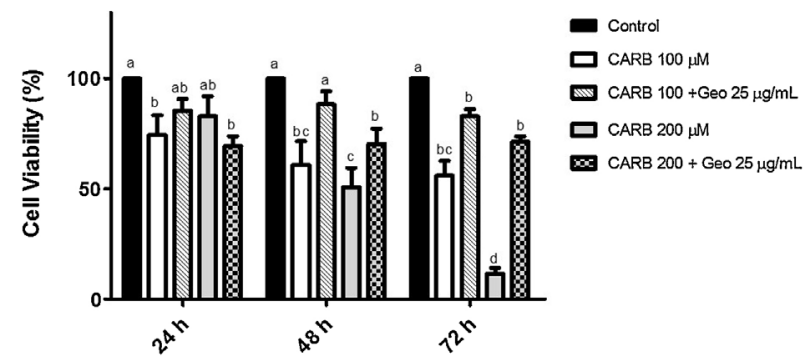

(c)

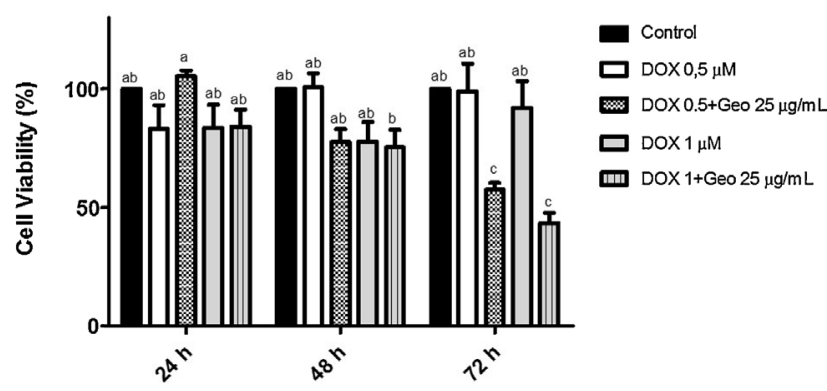

Fig. 6. Viability (\%) of HEp-2 cells treated with geopropolis (Geo-25 $\mu \mathrm{g} / \mathrm{ml}$ ) and methothrexate (MXT-50 and $100 \mu \mathrm{M})(\mathrm{a}) ; \mathrm{Geo}(25 \mu \mathrm{g} / \mathrm{ml})$ and carboplatin (CARB100 and $200 \mu \mathrm{M})(\mathrm{b}) ;$ Geo $(25 \mu \mathrm{g} / \mathrm{ml})$ and doxorubicin (DOX-0.5 and $1 \mu \mathrm{M})(\mathrm{c})$ after 24,48 and $72 \mathrm{~h}$ incubation. Different letters indicate significant differences between the treatments $(p<0.05)$.
DOX concentrations did not affect Vero cells viability $(p>0.05)$ after $72 \mathrm{~h}$, indicating that this drug did not exert cytotoxic effects towards non-tumoral cells (Fig. 7).

\subsection{Apoptotic effect of Geo and DOX on HEp-2 cells}

To examine whether Geo $(25 \mu \mathrm{g} / \mathrm{ml})$, DOX $(1 \mu \mathrm{M})$ and their combination could induce apoptosis after $72 \mathrm{~h}$, cells were stained with Annexin V-FITC and analyzed by flow cytometry. As shown in Fig. 8, DOX or Geo alone induced cell apoptosis/necrosis (Q1 + Q2: 16.28 and $11.53 \%$, respectively). The percentage of apoptotic cells increased in comparison to control group (9.31\%). The percentage of apoptotic cells was significantly higher after incubation with Geo + DOX (30.11\%) compared to DOX and Geo alone. A higher percentage of necrotic cells were seen after incubation of HEp2 cells with the combination Geo + Dox (Q2 + Q3: 28.57\%).

\subsection{Morphological changes}

HEp-2 cells treated with Geo + DOX exhibited fragmentations of cytoplasmic membrane (apoptotic bodies) and loss of membrane integrity, what is characteristic of late apoptotic/necrosis. As shown in Fig. 9, the combination increased the alterations in the cell morphology.

\subsection{Effects of verapamil on sensitivity of HEp-2 cells to Geo + DOX}

The sensitivity of HEp-2 cells to DOX was examined after co-treatment with a P-gp inhibitor: VRP (Fig. 10). DOX alone did not influence cell viability, whereas the co-treatment with VRP diminished the efflux of this drug by inhibiting P-gp, decreasing cell viability.

Geo + DOX decreased cell viability, and the co-incubation with VRP revealed that this combination exerted a similar action to DOX alone.

\section{Discussion}

Drug combination therapies are commonly used in cancer treatment in order to obtain better results and reduce drug resistance [23]. To address these problems, attention has been focused on identifying novel agents that can be combined with antitumor drugs to increase the therapeutic efficacy and decrease side effects. Recently, some studies have reported that some natural products combined with chemotherapeutic drugs enhanced the anticancer effects against various cell lines [24-27]. In the present study, the effects of Geo, a stingless bee product,

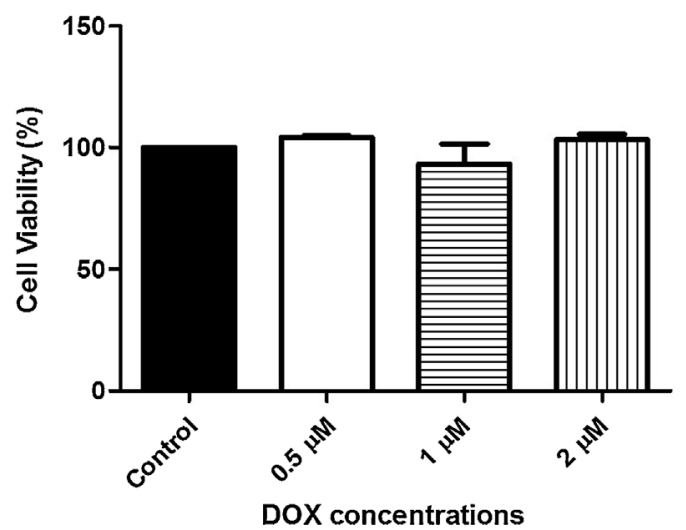

Fig. 7. Viability (\%) of Vero cells after incubation with different concentrations of doxorubicin (DOX-0.5, 1 and $2 \mu \mathrm{M}$ ) for $72 \mathrm{~h}$, by the MTT assay. Data represent means \pm standard-deviation of three experiments $(p>0.05)$. 

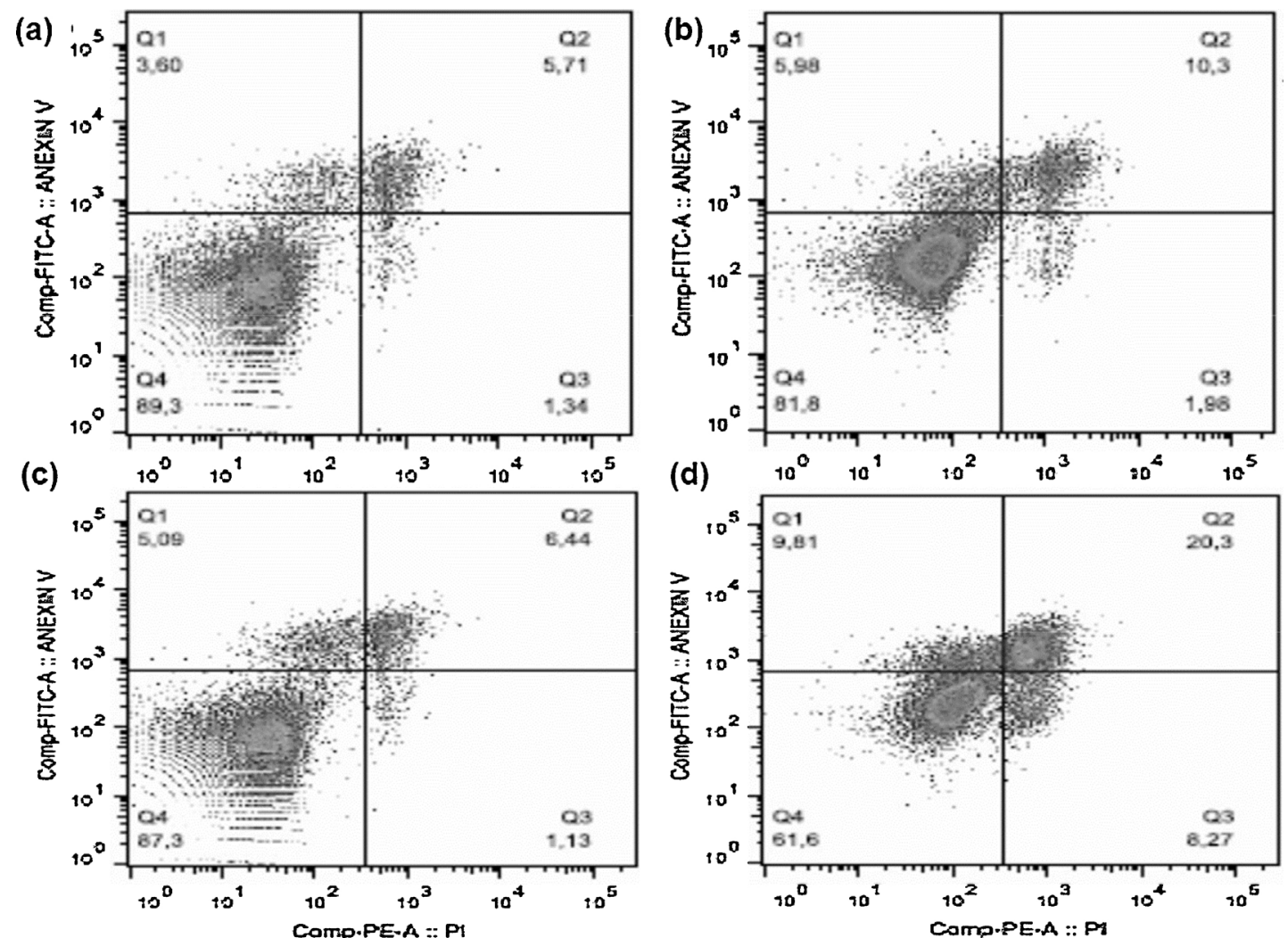

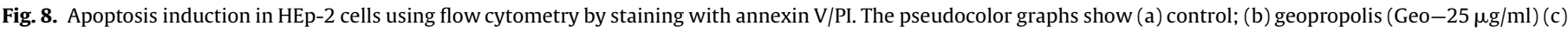

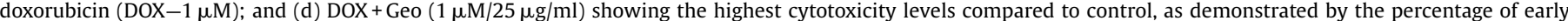

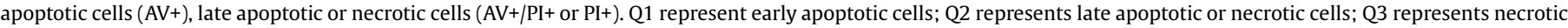
cells; Q4: live cells.

combined with DOX, MXT and CARB were investigated on HEp-2 cells. To determine whether Geo enhanced the anticancer effect of such drugs, HEp-2 cells were treated with Geo alone or in combination with each chemotherapeutic drugs and cell proliferation and migration, morphological changes, apoptosis and P-gp activity were evaluated.
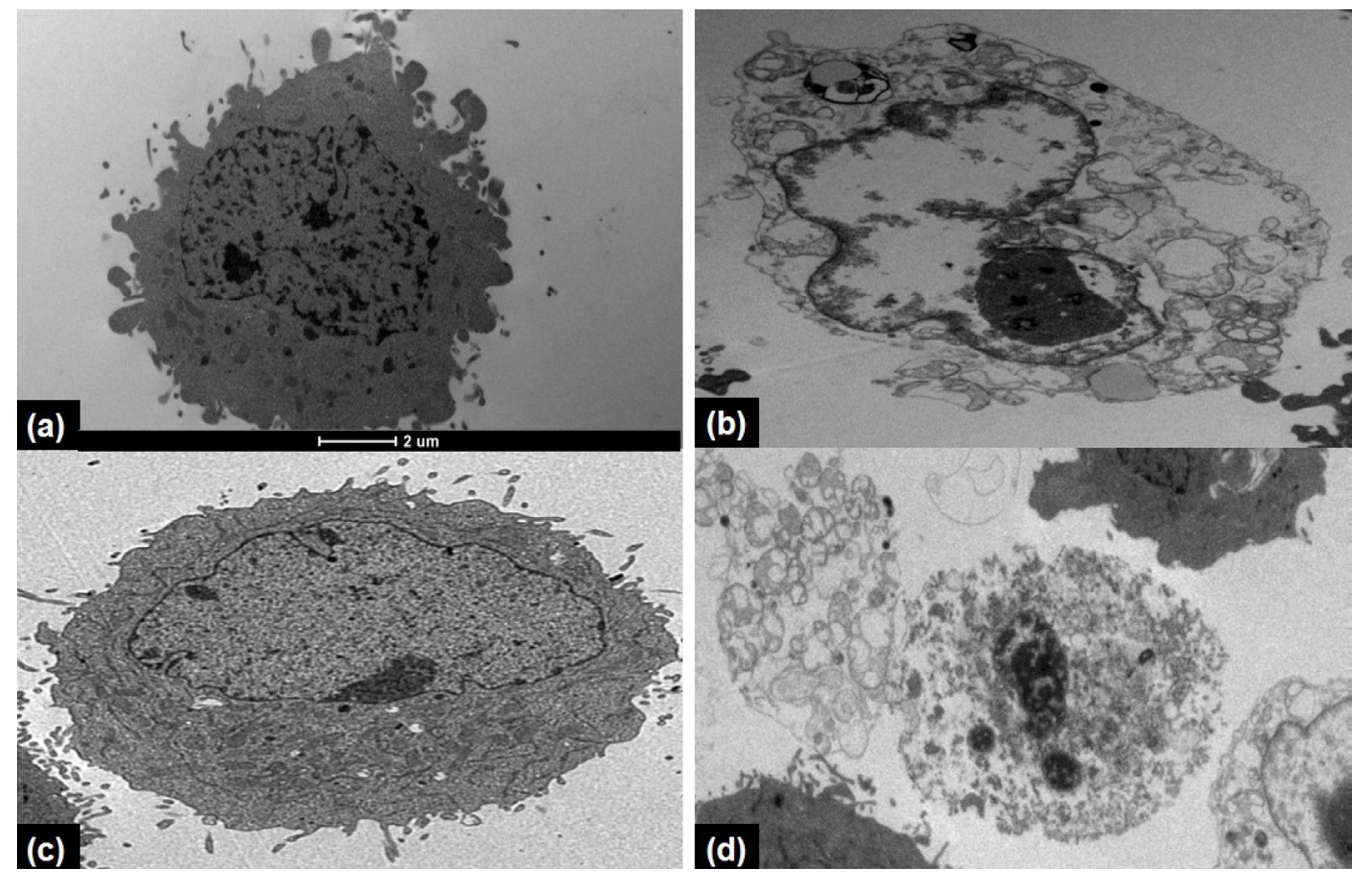

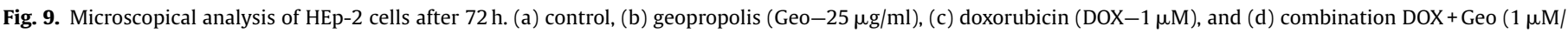
$25 \mu \mathrm{g} / \mathrm{ml}$ ), showing apoptotic/necrotic cells with loss of membrane integrity. Scale bar represents $2 \mu \mathrm{m}$. 


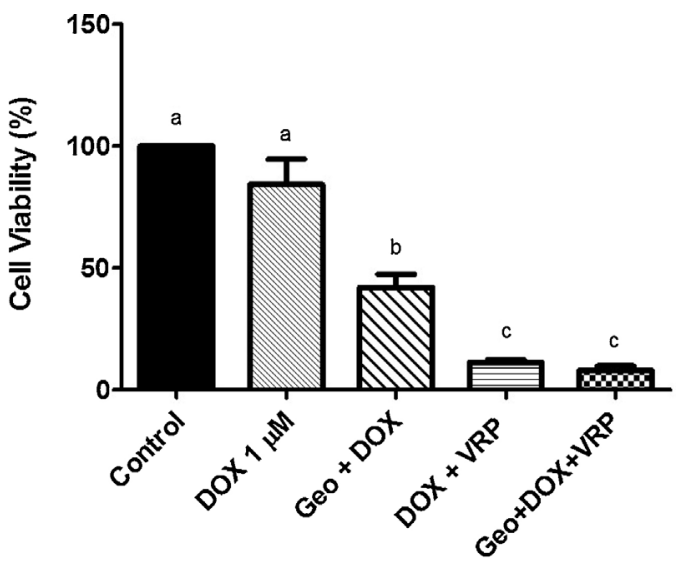

Treatments

Fig. 10. Effects of a P-gp inhibitor (verapamil-VRP, $5 \mu \mathrm{M}$ ) on the viability (\%) of HEp-2 cells incubated with doxorubicin (DOX-1 $\mu \mathrm{M}$ ), geopropolis (Geo-25 $\mu \mathrm{g}$ / $\mathrm{ml}$ ), and Geo+DOX for $72 \mathrm{~h}$. Different letters indicate significant differences between the groups $(p<0.05)$.

The proliferation of HEp-2 cells was reduced by Geo treatment in a time- and dose-dependent manner, showing selectivity against tumor cells compared to non-tumoral Vero cells. LDH leakage assay was also performed as indicator of cytotoxicity. LDH leakage increased in a dose-dependent manner after incubation of HEp-2 cells with Geo. Moreover, our data showed that the migration capacity of tumor cells decreased significantly after Geo treatment in vitro. The biological effects of Geo may be determined by its chemical composition. One may speculate that the antiproliferative and cytotoxic activity exerted by Geo may be due to the presence of Geo constituents such as lupeol, amyrins and anacardic acid and derivatives found in our sample [6]. These compounds have already been described by their cytotoxic action against different tumor cell lines [28-31].

The combination Geo + DOX exhibited a higher efficacy by inhibiting HEp- 2 cells growth than CARB and MXT, suggesting that Geo may act differentially in combination with drugs. In this work, Geo enhanced the inhibitory action of DOX against HEp-2 cells; in contrast, it diminished CARB activity. Sforcin and Bankova reported that possible interactions between propolis and other medicines should be investigated in humans [32]; therefore, further investigation should evaluate whether Geo enhances or diminishes the antitumoral action of drugs in vivo.

The antiproliferative potential of different chemotherapeutic agents in association with natural compounds may vary according to the sensitivity and cancer cell lines [33]. DOX is one of the widely used anticancer drugs in the treatment of various malignancies, but its clinical use is limited due to severe side effects to nontumoral cells $[34,35]$. The mechanism of action of DOX comprises the inhibition of cell proliferation and induction of apoptosis [36]. However, DOX-mediated cytotoxicity is different towards cancer and normal tissues depending of concentration in vivo and in vitro $[37,38]$. The present study showed no cytotoxic effects of DOX $(0.5$, 1 and $2 \mu \mathrm{M}$ ) on VERO cells and demonstrated the effectiveness of Geo + DOX against HEp- 2 cells. It has been reported that differences in DOX-mediated toxicity may be used as an alternative to improve the antitumor therapy with DOX [26,39].

To assess possible mechanisms involved in the anticancer activity of the combination Geo + DOX, the induction of apoptosis of HEp- 2 cells was evaluated by flow cytometry. Apoptosis plays a fundamental role in protecting organisms against tumorigenesis [40]. Apoptosis dysregulation is commonly found in cancer cells and its induction has been described as a strategy in cancer therapy
[41-43]. Our findings showed that the treatment of HEp-2 cells with Geo in combination with DOX induced apoptosis compared to Geo or DOX alone. These data are in agreement with the images obtained by transmission electron microscopy, showing the presence of apoptotic cells after treatment with Geo+DOX. Additionally, several studies have demonstrated that combination between DOX and different natural products can induce apoptosis [44-46]. Our data indicated for the first time that the combination of Geo extract and DOX exhibited a significant apoptotic potential.

To address whether the combination Geo + DOX could affect P-gp activity, HEp-2 cells were co-treated with VRP. DOX is a P-gp substrate and may modulate its expression, inducing cell resistance by increasing drug efflux [47]. P-gp is expressed by several cells and it is highly specific to eliminate hydrophobic compounds, such as chemotherapeutic agents, taxanes, topoisomerase inhibitors and antimetabolites [48,49]. VRP is a calcium channel blocker and a P-gp inhibitor at concentrations 5-10 $\mu \mathrm{M}$. It has been associated with reversion of resistance caused by P-gp action in vitro $[19,50]$. The treatment concomitantly with VRP increased significantly the sensitivity of HEp-2 cells to DOX, decreasing its efflux. In the presence of VRP, the effects of the combination Geo + DOX were similar to DOX, suggesting that Geo did not affect P-gp-mediated efflux of DOX and indicating that Geo may affect cell viability by other mechanisms. Similarly, a decreased HEp2 cell viability was seen after incubation with VRP, DOX and another natural product-curcumin, which had no effects on P-gp [19]. On the contrary, it has been suggested that propolis extract inhibited the function of MDR1 and increased the sensitivity to substrates of MDR1 in HeLa/TXL cells, suggesting that the propolis effects could be due to other constituents than caffeic acid phenethyl ester (CAPE) [51].

Altogether, our findings in vitro showed that Geo inhibited the proliferation and migration of human laryngeal carcinoma cells in vitro. Moreover, Geo enhanced the anticancer effect of DOX on HEp-2 cells by inducing apoptosis, morphological changes including apoptotic bodies, secondary apoptosis/necrosis and membrane dysruption, with no effects on P-gp action.

The effect of natural products associated to chemotherapeutic agents may be dependent on the type of agent, the characteristics of the tumor cells and/or the chemical composition of the natural product. The antitumor potential of the combination Geo + DOX should be further investigated in vivo not only to understand its mechanisms of action for clinical chemotherapeutic approaches but also using lower concentrations of drugs and aiming at fewer side effects to patients, since DOX may cause several adverse effects in different organs such as kidney, liver, and brain [52].

\section{Conflict of interest}

The authors declare that they have no conflict of interest.

\section{References}

[1] P. Deres, R. Halmosi, A. Toth, K. Kovacs, A. Palfi, T. Habon, L. Czopf, T. Kalai, K. Hideg, B. Sumegi, K. Toth, Prevention of doxorubicin-induced acute cardiotoxicity by an experimental antioxidant compound, J. Cardiovasc. Pharmacol. 45 (2005) 36-43.

[2] Y. Sadzuka, H. Hatakeyama, T. Sonobe, Enhancement of doxorubicin concentration in the M5076 ovarian sarcoma cells by cucurbitacin E co-treatment, Int. J. Pharm. 383 (2010) 186-191.

[3] X. Zhao, Q. Chen, Y. Li, H. Tang, W. Liu, X. Yang, Doxorubicin and curcumin co-delivery by lipid nanoparticles for enhanced treatment of diethylnitrosamine-induced hepatocellular carcinoma in mice, Eur. J. Pharm. Biopharm. 93 (2015) 27-536.

[4] S.A. Libério, A.L. Pereira, R.P. Dutra, A.S. Reis, M.J. Araújo, N.S. Mattar, L.A. Silva, M.N. Ribeiro, F.R. Nascimento, R.N. Guerra, V. Monteiro-Neto, Antimicrobial activity against oral pathogens and immunomodulatory effects and toxicity of geopropolis produced by the stingless bee Melipona fasciculata Smith, BMC Complement. Altern. Med. 2011 (2011) 1-10. 
[5] W.E. Kerr, G.A. Carvalho, V.A. Nascimento, Abelha uruçu: biologia, manejo e conservação, Fundação Acangaú, Belo Horizonte, MG, n. 2 (1996) 154 pp.

[6] M.J.A.M. Araújo, M.C. Búfalo, A. Fernandes Jr., B. Trusheva, V. Bankova, J.M. Sforcin, The chemical composition and pharmacological activities of geopropolis produced by Melipona fasciculata Smith in northeast Brazil, J. Mol Pathophysiol. 4 (2015) 12-20.

[7] L. Beketic-Oreskovic, M. Osmak, Human larynx carcinoma cells resistant to cisdiamminedichloroplatinum(II) cross-resistance pattern, Neoplasma 41 (1994) 171-176.

[8] T. Taguchi, G. Nishimura, M. Takahashi, M. Komatsu, D. Sano, N. Sakuma, N. Sakuma, Y. Arai, Y. Yamashita, O. Shiono, M. Hirama, Y. Sakuma, J. Ishitoya, M. Hata, I. Ogino, N. Oridate, Treatment results and prognostic factors for advanced squamous cell carcinoma of the larynx treated with concurrent chemoradiotherapy, Cancer Chemother. Pharmacol. 72 (2013) 837-843.

[9] V. Noronha, A. Joshi, S. Marfatia, V. Patil, S. Juvekar, S. Arya, S. Banavali, K. Prabhash, Health-related quality of life in patients with metastatic, relapsed, or inoperable squamous cell carcinoma of the head and neck in India, Support. Care Cancer 24 (2016) 1595-1602.

[10] D.B. Sawyer, X. Peng, B. Chen, L. Pentassuglia, C.C. Lim, Mechanisms of anthracycline cardiac injury: can we identify strategies for cardioprotection? Prog. Cardiovasc. Dis. 53 (2010) 105-113.

[11] D. Ding, B.L. Allman, R. Salvi, Review: ototoxic characteristics of platinum antitumor drugs, Anat. Rec. 295 (2012) 1851-1867.

[12] S.M. Ragab, E.A. Badr, Evaluation of serum and urine fetuin-A levels in children with acute lymphoblastic leukemia during and after high-dose methotrexate therapy: relation to toxicity, Hematology (2016) (in press).

[13] G. Szakacs, J.K. Paterson, J.A. Ludwig, C. Booth-Genthe, M.M. Gottesman, Targeting multidrug resistance in cancer, Nat. Rev. Drug Discov. 5 (2006) 219-234.

[14] B. Saedi, E. Razmpa, M. Sadeghi, M. Mojtahed, A. Mojtahed, The epidemiology of laryngeal cancer in a country on the esophageal cancer belt, Indian J. Otolaryngol. Head Neck Surg. 61 (2009) 213-217.

[15] L. Chatenoud, W. Garavello, E. Pagan, P. Bertuccio, S. Gallus, C. La Vecchia, E. Negri, C. Bosetti, Laryngeal cancer mortality trends in European countries, Int. J. Cancer 138 (2015) 833-842.

[16] C.J. Lin, J.R. Grandis, T.E. Carey, S.M. Gollin, T.L. Whiteside, W.M. Koch, R.L Ferris, S.Y. Lai, Head and neck squamous cell carcinoma cell lines: established models and rationale for selection, Head Neck 29 (2007) 163-188.

[17] N.C. Cinegaglia, P.R.O. Bersano, M.J.A.M. Araújo, M.C. Búfalo, J.M. Sforcin, Anticancer effects of geopropolis produced by stingless bees on canine osteosarcoma cells in vitro, Evid. Based Complement. Altern. Med. 2013 (2013) $1-6$.

[18] N. Duran, A.M. Allahverdiyev, S. Çetiner, Flow cytometric analysis of the effects of methotrexate and vespid on the HEp-2 cell cycle, Turk. J. Med. Sci. 31 (2001) 187-192.

[19] A. Harbottle, A.K. Daly, K. Atherton, F.C. Campbell, Role of glutathione S-transferase P1, P-glycoprotein and multidrug resistance-associated protein 1 in acquired doxorubicin resistance, Int. J. Cancer 92 (2001) 777-783.

[20] P.J. Schuler, S. Trellakis, J. Greve, M. Bas, C. Bergmann, E. Bolke, G. Lehnerdt, S Mattheis, A.E. Albers, S. Brandau, S. Lang, T.L. Whiteside, H. Bier, T.K. Hoffmann, In vitro chemosensitivity of head and neck cancer cell lines, Eur. J. Med. Res. 15 (2010) 337-344.

[21] T. Mosmann, Rapid colorimetric assay for cellular growth and survival: application to proliferation and cytotoxicity assays, J. Immunol. Methods 65 (1983) 55-63.

[22] C.C. Liang, A.Y. Park, J.L. Guan, In vitro scratch assay: a convenient and inexpensive method for analysis of cell migration in vitro, Nat. Protoc. 2 (2007) 329-333.

[23] N.L. Komarova, C.R. Boland, Cancer: calculated treatment, Nature 499 (2013) 291-292.

[24] V.M. Duarte, E. Han, M.S. Veena, A. Salvado, J.D. Suh, L.J. Liang, K.F. Faull, E.S Srivatsan, M.B. Wang, Curcumin enhances the effect of cisplatin in suppression of head and neck squamous cell carcinoma via inhibition of IKK $\beta$ protein of the NFkB pathway, Mol. Cancer Ther. 9 (2010) 2665-2675.

[25] S.H. Jafri, J. Glass, R. Shi, S. Zhang, M. Prince, H. Kleiner-Hancock, Thymoquinone and cisplatin as a therapeutic combination in lung cancer: in vitro and in vivo, J. Exp. Clin. Cancer Res. 29 (2010) 87.

[26] M.A. Khan, M. Singh, M.S. Khan, A.K. Najmi, S. Ahmad, Caspase mediated synergistic effect of Boswellia serrata extract in combination with doxorubicin against human hepatocellular carcinoma, Biomed. Res. Int. 2014 (2014) 1-11.

[27] S. Uesato, H. Yamashita, R. Maeda, Y. Hirata, M. Yamamoto, S. Matsue, Y Nagaoka, M. Shibano, M. Taniguchi, K. Baba, M. Ju-ichi, Synergistic antitumor effect of a combination of paclitaxel and carboplatin with nobiletin from Citrus depressa on non-small-cell lung cancer cell lines, Planta Med. 80 (2014) 452-457.

[28] I. Murtaza, M. Saleem, V.M. Adhami, B.B. Hafeez, H. Mukhtar, Suppression of cFLIP by lupeol a dietary triterpene, is sufficient to overcome resistance to TRAIL-mediated apoptosis in chemoresistant human pancreatic cancer cells, Cancer Res. 69 (2009) 1156-1165.
[29] F.W. Barros, P.N. Bandeira, D.J. Lima, A.S. Meira, S.S. Farias, M.R. Albuquerque, H. S. dos Santos, T.L. Lemos, M.O. de Morais, L.V. Costa-Lotufo, O. Pessoa Cdo, Amyrin esters induce cell death by apoptosis in HL-60 leukemia cells, Bioorg. Med. Chem. 19 (2011) 1268-1276.

[30] T.K. Lee, A. Castilho, V.C. Cheung, K.H. Tang, S. Ma, I.O. Ng, Lupeol targets liver tumor-initiating cells through phosphatase and tensin homolog modulation, Hepatology 53 (2011) 160-170.

[31] D. Alam-Escamila, E. Estrada-Muniz, E. Solis-Villegas, G. Elizondo, Genotoxic and cytostatic effects of 6-pentadecyl salicylic anacardic acid in transformed cell lines and peripheral blood mononuclear cells, Mutat. Res. Genet. Toxicol. Environ. Mutagen. 777 (2015) 43-53.

[32] J.M. Sforcin, V. Bankova, Propolis: is there a potential for the development of new drugs? J. Ethnopharmacol. 133 (2011) 256-260.

[33] S.Y. Eid, M.Z. El-Readi, M. Wink, Synergism of three-drug combinations of sanguinarine and other plant secondary metabolites with digitonin and doxorubicin in multi-drug resistant cancer cells, Phytomedicine 19 (2012) 1288-1297.

[34] P.D. King, M.C. Perry, Hepatotoxicity of chemotherapy, Oncologist 6 (2001) 162-176.

[35] C. Carvalho, R.X. Santos, S. Cardoso, S. Correia, P.J. Oliveira, M.S. Santos, P.I. Moreira, Doxorubicin: the good, the bad and the ugly effect, Curr. Med. Chem. 16 (2009) 3267-3285.

[36] S. Wang, E.A. Konorev, S. Kotamraju, J. Joseph, S. Kalivendi, B. Kalyanaraman, Doxorubicin induces apoptosis in normal and tumor cells via distinctly different mechanisms. Intermediacy of $\mathrm{H}_{2} \mathrm{O}_{2}$ - and p53-dependent pathways, J. Biol. Chem. 279 (2004) 25535-25543.

[37] P. Mukhopadhyay, M. Rajesh, S. Batkai, Y. Kashiwaya, G. Hasko, L. Liaudet, C. Szabo, P. Pacher, Role of superoxide nitric oxide, and peroxynitrite in doxorubicin-induced cell death in vivo and in vitro, Am. J. Physiol. Heart Circ. Physiol. 296 (2009) 1466-1483.

[38] O. Hovorka, V. Subr, D. Vetvicka, L. Kovar, J. Strohalm, M. Strohalm, A. Benda, K. Ulbrich, B. Rihova, Spectral analysis of doxorubicin accumulation and the indirect quantification of its DNA intercalation, Eur. J. Pharm. Biopharm. 76 (2010) 514-524.

[39] L.J. Carlson, B. Cote, A.W. Alani, D.A. Rao, Polymeric micellar co-delivery of resveratrol and curcumin to mitigate in vitro doxorubicin-induced cardiotoxicity, J. Pharm. Sci. 103 (2014) 2315-2322.

[40] C.Z. Liang, J.K. Zhang, Z. Shi, B. Liu, C.Q. Shen, H.M. Tao, Matrine induces caspase-dependent apoptosis in human osteosarcoma cells in vitro and in vivo through the upregulation of Bax and Fas/FasL and downregulation of Bcl-2, Cancer Chemother. Pharmacol. 69 (2012) 317-331.

[41] J.H. Kim, Y.W. Choi, C. Park, C.Y. Jin, Y.J. Lee, D.J. Park, S.G. Kim, G.Y. Kim, Y.H. Choi, W.D. Hwang, Y.K. Jeong, S.K. Kim, Y.H. Choi, Apoptosis induction of human leukemia U937 cells by gomisin N a dibenzocyclooctadiene lignan, isolated from Schizandra chinensis Baill, Food Chem. Toxicol. 48 (2010) 807-813.

[42] P.N. Kelly, A. Strasser, The role of Bcl-2 and its pro-survival relatives in tumourigenesis and cancer therapy, Cell Death Differ. 18 (2011) 1414-1424

[43] A. Strasser, S. Cory, J.M. Adams, Deciphering the rules of programmed cell death to improve therapy of cancer and other diseases, EMBO J. 30 (2011) 3667-3683.

[44] M.S. Kwak, S.J. Yu, J.H. Yoon, S.H. Lee, S.M. Lee, J.H. Lee, Y.J. Kim, H.S. Lee, C.Y. Kim, Synergistic anti-tumor efficacy of doxorubicin and flavopiridol in an in vivo hepatocellular carcinoma model, J. Cancer Res. Clin. Oncol. 141 (2015) 2037-2045.

[45] H. Li, M. Li, C. Chen, A. Fan, D. Kong, Z. Wang, Y. Zhao, On-demand combinational delivery of curcumin and doxorubicin via a pH-labile micellar nanocarrier, Int. J. Pharm. 495 (2015) 572-578.

[46] J. Zhu, X. Xu, M. Hu, L. Qiu, Co-encapsulation of combretastatin-a4 phosphate and doxorubicin in polymersomes for synergistic therapy of nasopharyngeal epidermal carcinoma, J. Biomed. Nanotechnol. 11 (2015) 997-1006.

[47] C.S. Yan, I.L. Wong, K.F. Chan, J.W. Kan, T.C. Chong, M.C. Law, Y. Zhao, S.W. Chan, T.H. Chan, L.M. Chow, A new class of safe, potent, and specific P-gp modulator: flavonoid dimer fd18 reverses P-gp-mediated multidrug resistance in human breast xenograft in vivo, Mol. Pharm. 12 (2015) 3507-3517.

[48] S.V. Ambudkar, S. Dey, C.A. Hrycyna, M. Ramachandra, I. Pastan, M.M. Gottesman, Biochemical cellular, and pharmacological aspects of the multidrug transporter, Annu. Rev. Pharmacol. Toxicol. 39 (1999) 361-398.

[49] C.H. Choi, ABC transporters as multidrug resistance mechanisms and the development of chemosensitizers for their reversal, Cancer Cell Int. 5 (2005) 30.

[50] H.M. Abdallah, A.M. Al-Abd, R.S. El-Dine, A.M. El-Halawany, P-glycoprotein inhibitors of natural origin as potential tumor chemo-sensitizers: a review, J. Adv. Res. 6 (2015) 45-62.

[51] K. Takara, M. Fujita, M. Matsubara, T. Minegaki, N. Kitada, N. Ohnishi, T. Yokoyama, Effects of propolis extract on sensitivity to chemotherapeutic agents in HeLa and resistant sublines, Phytother. Res. 21 (2007) 841-846.

[52] C. Carvalho, R.X. Santos, S. Cardoso, S. Correia, P.J. Oliveira, M.S. Santos, P.I. Moreira, Doxorubicin: the good, the bad and the ugly effect, Curr. Med. Chem. 16 (2009) 3267-3285. 